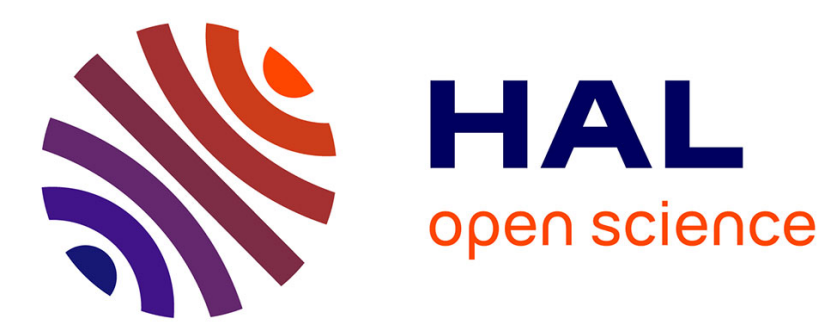

\title{
Thorstein Veblen's 1904 contributions to Q and insider/outsider analysis
}

Marion Dieudonné

\section{To cite this version:}

Marion Dieudonné. Thorstein Veblen's 1904 contributions to Q and insider/outsider analysis. 2016. hal-01313309

\author{
HAL Id: hal-01313309 \\ https://hal.science/hal-01313309
}

Preprint submitted on 9 May 2016

HAL is a multi-disciplinary open access archive for the deposit and dissemination of scientific research documents, whether they are published or not. The documents may come from teaching and research institutions in France or abroad, or from public or private research centers.
L'archive ouverte pluridisciplinaire HAL, est destinée au dépôt et à la diffusion de documents scientifiques de niveau recherche, publiés ou non, émanant des établissements d'enseignement et de recherche français ou étrangers, des laboratoires publics ou privés. 


\section{Thorstein Veblen's 1904 contributions to Q and insider/outsider analysis}

\section{Introduction}

In this paper we point out that as early as 1904, Veblen showed the non-neutrality of the financial structure, and that is why it is important not to overlook him in the rational reconstruction of Q theory and the analysis of corporate finance.

Since the beginning of the $20^{\text {th }}$ century, great economists have sought to explain the relation between corporate finance, investment and financial structure. We compare the European tradition with the American one - in which we present mainly Thorstein Veblen - and seek to understand their mutual influences. We reconstruct Q theory, describing precisely an explanatory schema of a little-known tradition (or at least of neglected influence): investment theory. The goal is to make a critical contribution in relation to the primary and secondary literature on the theories in question and their issues; and so to situate Veblen within this tradition.

In essence, a company seeks to achieve good economic results. Value creation is an imperative of business processes and corporate management. This article is rooted in the context that addressed issues of financial theory of investment at the beginning of the 20th century. Although principles and practice already existed, it was in this period that corporate finance became a theoretical discipline. Indeed, many textbooks were published in the decades 1910-1920 affirming a real interest in it. Thorstein Veblen (1904, 1908, and 1923) was one of the theorists interested in the company and its management, from 1904. It would take some 80 years for this branch of economics to impose its legitimacy. Furthermore, regarding the company's financial structure, it was not until 1958 that Franco Modigliani and Merton Miller made an epistemological break with the analysis of these previous economists, of the non-neutrality of financing methods.

The writings of John Maynard Keynes (1930, 1936), Gunnar Myrdal (1931, 1933) and James Tobin $(1968,1969)$ dealt with the development of an investment theory based on the financial structure. They contributed to an understanding of the role of financial 
structure in business management. Furthermore, Karl Marx (1864-1875 ${ }^{1}$ ) and Rudolph Hilferding (1910) with his analysis of the promoter's profit, also contributed to this tradition of thought. However, these studies do not mention Thorstein Veblen, one of the founding fathers of institutionalism, who remains little-known, although a recent literature considers that he provides an interesting contribution to capital theory (Ganley, 2004; Gagnon, 2007; Cochrane, 2011; Mendez, 2012). Indeed, in his Theory of Business Enterprise of 1904, Veblen carried out an early American analysis of corporate governance structure, later highlighted by Adolf Berle and Gardiner Means (1932), which appeared as a real issue in the early $20^{\text {th }}$ century in view of the development of financial instruments, shareholder behavior and corporate equity valuation concerns. The theory of the non-neutrality of the financial structure retains all it pertinence today, so that in this paper, we will focus on the reasons why Veblen's corporate financial analysis should not be overlooked.

The first part of the article (sections 1 to 3) studies the analysis of investment as a consequence of financial assets valuation. The first section retraces the tradition of analysis of the role of the financial structure in business investment between 1898 and 1969, emphasizing the filiation from Knut Wicksell to James Tobin. We present this investment theory from the perspective of different Q-theories that the literature has identified (Dimand, 2014). We establish a new presentation of the Wicksellian and Keynesian theories that is of interest for understanding the Q-theories. In the third section of this first part, we show that Veblen fits into this analysis of investment as a consequence of financial asset valuation, and yet he remains a forgotten theorist of corporate finance. There is a literature studying the links between different Q-theories and a quite similar analysis of investment and corporate capital in Veblen's works (Bolbol \& Lovewell, 2001; Medlen, 2003, Dimand, 2004). However, surprisingly, it does not establish any relation between Veblenian goodwill, the investment windfall profit of Keynes, Myrdal's Q and Tobin's q.

\footnotetext{
${ }^{1}$ Capital, vol. III, ed.1894
} 
Consequently, we present Veblen as a precursor, since 1904, of analysis in terms of company capitalization ${ }^{2}$ and its financial structure with the formalization of a Veblen's Q.

In the second part of the paper (sections 4 and 5), we pursue the analysis by presenting Veblen alongside his contemporaries and pointing out that he was a pioneer of managerial capitalism and financial corporate analysis. We focus on the analysis of the link between investment, financing and governance. In section 4 we clarify the divergence between Veblen and contributors to Q theory concerning the consequences of corporate additional value. While the latter developed a theory of investment, Veblen related analysis of the financial structure to business management concerns. This leads us to consider Veblen's relation to and influence on European theorists (Rubel, 1968; Berle and Means, 1932). We stress the strategic objectives and characteristics of capitalistentrepreneurs and shareholders and the use of the credit leverage effect, with a connection to Marx and Hilferding. This allows us to establish the link, later emphasized by Berle and Means, between the separation of ownership and management functions. We then present Veblen as one of the early contributors to Q and insider/outsider analysis.

\section{Wicksell as a precursor of Myrdal's $Q$}

Through the concepts of financial structure, company's market value and investment we present a perspective of Q-theories, revisiting firstly the theory of Wicksell interpreted by Myrdal and then the theory of Keynes. We also insert Veblen into this paradigm: Q theory is not rooted solely in Tobin's thought. We thus bring to light a long tradition of reflection on investment, a consensus - "soft" regarding Wicksell and Veblen - that changes with the concepts used by the authors.

According to Klaus Schmidt $(1995,197)$, there is a tradition of analysis linking investment to the financial structure of the company, which has its origins in the writings of Wicksell (1898) and Keynes (1930, 1936). By financial structure we mean the balance of company resources (equity and debts), used to determine the financial balance, to

\footnotetext{
${ }^{2}$ Veblen has the reputation of being a difficult writer to read. See Dieudonné (2014) for more details on the trialand-error nature of his thinking about capitalization of assets.
} 
diagnose viability and to guide business decisions. ${ }^{3}$ Moreover, thanks to Schmidt, who was a student of Gunnar Myrdal, the latter was recognized as one of the pioneers of what was later called Q theory. Especially since Myrdal's Q first appeared in his 1931 article in Swedish and subsequently in his 1933 book, which was only really acknowledged in 1939 when the book was translated into English as Monetary Equilibrium.

The structure of investment depends on the capital financial valuation of the firm. Recent neoclassical developments in investment analysis do not just compare the performance of the investment with the monetary interest rate, they also use the valuation of the company on the financial market. For Tobin, "q is all that matters" (interviewed by Colander 1999, 120), because it is traditionally a guide to identify the determinants of investment and to evaluate the impact of the transmission to the market. ${ }^{4}$ James Tobin developed this theory in 1969 , proposing a q such that: $Q_{\text {Tobin }}=\frac{\text { Market value of Capital }}{\text { Replacement cost }}$. In our article, we use the following notation: $Q_{\text {Tobin }}=\frac{I}{I}^{5}$. But surprisingly, Tobin did not mention the works of Keynes or Myrdal. The filiation of Tobin with these authors was not recognized until the 1990s and the publication of Schmidt's article. ${ }^{6}$

In addition, to mark this major interest, a rather dense secondary literature searches for the sources and influences of investment determinants, of asset market movements and their transmission to the real economy in their works (Crotty, 1990, 1992; Schmidt, 1995; de Boyer, 2003; Dimand, 2014). In his 2014 book about Tobin, entitled "James Tobin”,

\footnotetext{
${ }^{3}$ Modern principles of the role of the structure in terms of financial value were developed in 1958 by ModiglianiMiller.

${ }^{4}$ The literature recognizes the central importance of Q theory. James Crotty $(1990,8)$ quotes the following passage from Stanley Fisher and Robert C. Merton $(1984,29)$ : "Q theory ... is now the preferred theoretical description of investment", despite the empirical and econometric debates of recent years. Notwithstanding the criticism that can be levelled at it concerning the non-uniqueness of the theory of investment to which it refers, and the concept of proxy with objective empirical tests, Q theory remains the most coherent framework for studying the influence of finance on investment. See E. Lindenberg and S. Ross (1981), A. Epaulard (1993), and G. Charreaux (1998) for the attractiveness of this proxy to circumvent the question of expectations, to diversify its use, or to corroborate empirical data and accounting results.

${ }^{5} \mathrm{So}$, I is the market value of capital and I' the replacement cost.

${ }^{6}$ In a footnote, Tobin and Golub $(1998,150)$ specify that: "Gunnar Myrdal $(1931,1933)$ long ago anticipated q, even called it Q! However, his Q was not a ratio but the absolute difference between market value and replacement cost. His articles were in Swedish and German, never English, not known to the authors of q until Klaus Schmidt, a graduate student at Johann Wolfgang Goethe University in Frankfurt called them to the author's attention in 1994. See Schmidt (1995).”
} 
Robert Dimand examines the question: "What are the historical roots of Tobin's q?" and analyzes the historiography of the Q theory in Chapter 5, “Tobin's $q$ and the Theory of Investment":

"Indeed the real message is that investment is related to discrepancies between the marginal efficiency and the interest rate. This is in the tradition of Wicksell and of Keynes's earlier work" (1930). (Dimand, 2014, 74-5)

However, this tradition was only recognized belatedly. Concerning Knut Wicksell, Dimand relies on Klaus Schmidt’s 1995 study “Tobin’s q? - Myrdal's Q! ein Fallbeispiel für den Wert von Fremdsprachenkeantaussen”. According to Schmidt, Wicksell presented an analysis comparing the natural and the monetary rates of interest in 1898, in Interest and Prices. This analysis was taken up and enriched in 1931 by Gunnar Myrdal, ${ }^{7}$ who gave it an interpretation in terms of financial investment valuation. ${ }^{8}$

The new interpretation of Myrdal by Schmidt, based on the Wicksellian system, ${ }^{9}$ led to the construction of a theory of investment choices:

"[Myrdal] details and modifies certain of Wicksell's ideas by reformulating the natural rate of interest as the marginal efficiency of capital and the rate of interest on money as the discount rate. Furthermore, he shows that the unobservable relationship between these two rates corresponds to the ratio between the market value and the replacement cost of real capital, for which a statistical representation can be constructed.” (Schmidt, 1995, 199)

A stock company makes a 2000 profit $(\pi)$. Following Wicksell, there are two interest rates: the market rate of interest $\left(\mathrm{r}_{\mathrm{M}}\right)$ and the natural rate $\left(\mathrm{r}_{\mathrm{N}}\right)$. Consider, for example, a market rate of $7 \%$ and a natural rate of $10 \% .{ }^{10}$ Profits capitalized at the respective rates give us:

$$
\begin{aligned}
& I=\frac{\pi}{r_{M}}=\frac{2000}{0.07}=28571 \\
& I^{\prime}=\frac{\pi}{r_{N}}=\frac{2000}{0.10}=20000
\end{aligned}
$$

\footnotetext{
${ }^{7}$ It should be noted that we lacked access to the original texts because they are written in Swedish. This obstacle to the dissemination of Myrdal's ideas has also been highlighted by Schmidt (1995), Tobin and Stephen Golub (1995) and Dimand (2014).

8 "Wicksell's concept of the 'natural' or 'real' rate of interest is [...] strongly related to a purely physical productivity" rather than "the yield of real capital" (Myrdal, 1939, 54).

${ }^{9}$ Wicksell used "money rate" $(1936,107)$ and "market rate" $(86,174)$ to mean the same thing.

${ }^{10}$ In his preface to Wicksell's Interest and Prices, Bertil Ohlin writes: "this natural rate is roughly the same thing as the real interest of actual business" (1936, xxv).
} 
Myrdal reinterprets Wicksell's analysis of the gap between the valuation of the firm and the value of investment. Thus, I represents the financial value of capital and I' the cost of reproduction of existing capital.

$$
\begin{aligned}
& I>I^{\prime} \\
& \Leftrightarrow r_{M}<r_{N} \\
\Leftrightarrow & I-I^{\prime}>0
\end{aligned}
$$

If the difference between natural rate ${ }^{11}$ and market rate is positive, there is a surplus value, so there is an investment. Otherwise, there is no incentive to invest. Thus, Myrdal compares the real value of the firm with its financial value, which marks a step forward from Wicksell's approach. ${ }^{12}$ Schmidt presents an analysis in which Wicksell can be interpreted in terms of Q, as in Myrdal.

$$
I-I^{\prime}=Q_{M Y R D A L}
$$

These results are also expounded in Monetary Equilibrium, published in 1933, where I is denoted $\mathrm{C}_{1}$ ("the value of existing capital") and I' is denoted $\mathrm{R}_{1}$ ("the cost of reproduction of existing capital").

\section{Keynes's $Q$ in 1930 and 1936}

In fact, Myrdal was not the first to speak of Q and to be inspired by Wicksell. According to Dimand, Keyne's Treatise on Money (1930) was “carefully studied by Myrdal” (Dimand 2014, 75) and, according to Myrdal, this Treatise "is completely permeated by Wicksell's influence” (Myrdal 1939, 8-9). However, Myrdal stresses that in the Treatise:

“The entrepreneur's activity commences immediately a difference in the interest rates appears, however small it may be" (Myrdal, 1965, 1939, I, 76),

whereas Keynes compares the financial valuation of capital I with its replacement cost I'. He defines the windfall profit on investment goods, denoted $\mathrm{Q}_{2}$ and equal to the difference between I and I': Q $2=$ I - I'13. The windfall profit increases with investment.

\footnotetext{
${ }^{11}$ The interest of this redefinition of the natural rate of interest appears to be the possibility of incorporating agents' expectations.

${ }^{12}$ Myrdal also underlines his dissatisfaction with Wicksell's system in a letter he wrote to Hayek (see Dostaler, 1991).

13 'I $=(\mathrm{P}$ ' [the price-level of new investment goods] $* \mathrm{C})$ is the value (as distinguished from I', the cost of production) of the increment of new investment goods" (Keynes, 1930, 1965, I, 137)
} 
Now, Schmidt $(1995,197)$ rightly identified the affiliation of Q theory with the Treatise on Money (1930), but he did not develop this idea.

In Chapter 9 of the Treatise, Keynes provides a set of definitions:

"But we exclude [from the normal remuneration of the entrepreneurs] their windfall profits or losses represented by the difference (positive or negative) between the earnings, thus defined, of the factors of production and the actual sale proceeds. The income of holders of ordinary shares will usually include elements of each of the items (b: the normal remuneration of entrepreneurs), (c: interest on capital) and (d: regular monopoly gains, rents and the like), and they will also be recipients of windfall profits and losses." (Keynes, 1930, 1965, I, 124)

For Keynes, the relative price of consumption goods and investment goods is not fixed. Keynes defines three "windfall profits": $\mathrm{Q}_{1}, \mathrm{Q}_{2}$, and $\mathrm{Q}=\mathrm{Q}_{1}+\mathrm{Q}_{2}$.

"Next, let $\mathrm{Q}_{1}$ be the amount of the profit (defined as above) on the production and sale of consumption, and $\mathrm{Q}_{2}$ the corresponding profit on investment goods, and $\mathrm{Q}$ the total profit.” (Keynes, 1930, 1965, I, 137)

In Chapter 10, The Fundamental Equation, Keynes writes C' for the cost of production of consumption goods, $\mathrm{E}\left(=\mathrm{C}^{\prime}+\mathrm{I}^{\prime}\right)$ for the money-income or earnings of the community, ${ }^{14} \mathrm{~S}$ for savings, and $\mathrm{C}$ the demand for consumption goods. ${ }^{15}$ Therefore, there are three kinds of windfall profits:

- The profit on consumption goods $Q_{1}=C-C^{\prime}=(E-S)-\left(E-I^{\prime}\right)=I^{\prime}-S$

- The profit on investment goods $Q_{2}=I-I^{\prime 16}$

- And the total profit $Q=Q_{1}+Q_{2}=\left(I^{\prime}-S\right)+\left(I-I^{\prime}\right)=I-S$.

Here, we are interested in investment, i.e. $\mathrm{Q}_{2}$. So, let us assume that $Q_{1}=0$ so that $Q=$ $Q_{2} \cdot{ }^{17}$

The contractor issues shares equal to $£ 20,000$ in order to finance an investment project by the same amount: I' $=£ 20,000$. But, because "the actual price-level of investments is the resultant of the sentiment of the public and the behavior of the banking system" (1930,

\footnotetext{
14 "Let $\mathrm{E}$ be the total money-income or Earnings of the community in a unit of time, and I' the part of it which has been earned by the production of investment-goods, so that I' measures the cost of production of new investment." (Keynes, 1930, 1965, I, 135)

15 "E-I' [is] the cost of production of the current output of consumption-goods." (Keynes, 1930, 1965, I, 135)

${ }^{16}$ (Keynes, 1930, 1965, I, 138)

${ }^{17}$ The fundamental equations of the Treatise on Money describe a two-sector production model where the excess demand for consumption goods does not result in an excess supply of investments goods. See de Boyer (1982).
} 
142), the contractor finally recovers $I=\$ 28,571$, from the sale of his shares. He buys $£ 28,571$ of capital goods so that the producers of these goods make a windfall profit $\mathrm{Q}_{2}$. The investment in capital goods is higher than the cost of production of capital goods, i.e. $\mathrm{Q}_{2}=\mathrm{I}-\mathrm{I}^{\prime}=£ 8,571$. According to Keynes, writing in 1930, I is the value of capital goods and I' is their replacement cost.

Now, concerning the determination of the valuation of I, Keynes reasoned in terms of capitalization. We can consider that, although it was not actually formulated as such, the following equation is consistent with its interpretation:

$$
I=\frac{\pi^{E}}{R_{M}}(\text { eq. } 1)
$$

The value of the company's capital assets is the result of the capitalization of expected returns $\pi^{E}$ at the capital market interest rate $R_{M} \cdot{ }^{18}$ Moreover, in Chapter 11 , The Conditions of Equilibrium, Keynes explained:

"The attractiveness of investment depends on the prospective income which the entrepreneur anticipates from current investment relatively to the rate of interest which he has to pay in order to be able to finance its production: - or, putting it the other way round, the value of capital-goods depends on the rate of interest at which the prospective income from them is capitalized." (Keynes, 1930, 1965, I, 154)

The interest rate involved corresponds to the market rate $\left(\mathrm{R}_{\mathrm{M}}\right)$. However, a few lines later he introduces the possibility of considering a natural rate:

"Following Wicksell, it will be convenient to call the rate of interest which would cause the second term of our second fundamental equation to be zero the natural rate of interest, and the rate which actually prevails the market rate of interest." (Keynes, 1930, 1965, I, 1545 , italics in original)

Here, the natural rate is a particular level of the market rate, corresponding to the case where $\mathrm{Q}=0$, i.e., $\mathrm{I}=\mathrm{I}$ '. Therefore, saying that $\mathrm{Q}=0$ means that $\mathrm{I}=\mathrm{S}$.

In 1936, Keynes's reasoning on investment was no longer based on capitalization values, but on a comparison between the market rate of interest and the marginal efficiency of capital. In fact, there is some continuity between the writings from 1930 and 1936, but with analytical divergences.

\footnotetext{
${ }^{18}$ Including a risk premium. Actually, the money rate can be found in the newspaper, as the market price, while the natural rate is hidden and deduced from exogenous variables.
} 
"The speed at which the capital stock was adjusted toward its desired level would depend on how far the marginal efficiency of capital was from the interest rate: 'In this view we were in the tradition of Wicksell and of the Keynes of A Treatise on Money (who occasionally reappears in the General Theory)'” (Tobin and Brainard 1990, 68, quoted by Dimand, 2014, 85-6)

In Chapter 11 of the General Theory, the equation $Q=$ I-I' does not appear. However, Keynes develops the notion of marginal efficiency of capital that refers to Q theory. Whereas in 1930 the cost of replacement I' intervenes in the determination of the natural rate of interest, in 1936 Keynes calls the same thing the marginal efficiency of capital. ${ }^{19}$

It then remains to demonstrate that:

$$
\frac{\pi^{E}}{R_{N}} \equiv \frac{\pi^{E}}{m e c} \lessgtr \frac{\pi^{E}}{R_{M}} \text { ie } I^{\prime} \lessgtr I
$$

"Over against the prospective yield of the investment we have the supply price of the capitalasset, meaning by this, not the market-price at which an asset of the type in question can actually be purchased in the market, but the price which would just induce a manufacturer newly to produce an additional unit of such assets, i.e. what is sometimes called its replacement cost. The relation between the prospective yield of a capital-asset and its supply price or replacement cost, i.e. the relation between the prospective yield of one more unit of that type of capital and the cost of producing that unit, furnishes us with the marginal efficiency of capital of that type." (Keynes, 1936, 1973, 135)

Although the books from 1930 and 1936 did use the same terminology, we can make the connection between the offer price I $(1930,137)$, and the replacement cost of I' (1930, 135; 1936). In fact, in 1936 the marginal efficiency of capital, thereafter mec, is used instead of $R_{N}$.

$$
\frac{\pi^{E}}{I^{\prime}}=m e c
$$

Thus, (eq. 2) appears as:

$$
\frac{\pi^{E}}{m e c}=I^{\prime}(\text { eq. } 2)
$$

And in parallel:

$$
\frac{\pi^{E}}{r_{M}}=I
$$

\footnotetext{
${ }^{19}$ In 1936 (1973, 140-1) Keynes referred at length to Irving Fisher (Theory of Interest, 1930), to explain that they shared the same understanding in Fisher's rate of return over cost and Keynes's marginal efficiency of capital. (See, Kregel, 1988, 64-65; de Boyer, 1988, 70 and Boianovsky, 2013, 212, 215, 217)
} 
The mec, capitalized rate applied to annuities series $\pi^{\mathrm{a}}$ is then compared to $\mathrm{r}_{\mathrm{M}}$. Ultimately, the mec is similar to Wicksell's natural rate. ${ }^{20}$

$$
\begin{aligned}
& \mathrm{R}_{\mathrm{M}}<\mathrm{mec} \Leftrightarrow \frac{\pi^{E}}{r_{M}}>\frac{\pi^{E}}{m e c} \Leftrightarrow \mathrm{I}>\mathrm{I}^{\prime} \Leftrightarrow \mathrm{I}-\mathrm{I}^{\prime}>0 \Leftrightarrow \mathrm{Q}>0 \\
& \mathrm{R}_{\mathrm{M}}>\operatorname{mec} \Leftrightarrow \frac{\pi^{E}}{r_{M}}<\frac{\pi^{E}}{m e c} \Leftrightarrow \mathrm{I}<\mathrm{I}, \Leftrightarrow \mathrm{I}-\mathrm{I}^{\prime}<0 \Leftrightarrow \mathrm{Q}<0
\end{aligned}
$$

In 1936, Keynes did not write the equation I-I', but he did provide all the elements needed to write a Q-Keynes.

$$
Q_{K E Y N E S}=\frac{\pi^{E}}{r_{M}}-\frac{\pi^{E}}{m e c}
$$

This tradition of analysis of the investment decision is particularly developed in Europe but little known and little analyzed in the literature of Q theory. But it was also an American specificity of the turn of the century to talk about the concentration of ownership and strategies of industrial groups. Today, only the Tobin's q theory remains, disconnected from its influences and roots, ${ }^{21}$ even though understanding all these links would allow us to address comprehensively the relationship between financial structure and investment strategies or business management. In the following section we will show that there is a tradition that analyzes the relationship between financial structure, company's market value and investment decisions, but which completely overlooks Veblen.

\footnotetext{
${ }^{20}$ However, although in Wicksell there is only one natural rate of interest, in Keynes (1936) there are many. "In my Treatise on Money I defined what purported to be a unique rate of interest, which I called the natural rate of interest - namely, the rate of interest which, in the terminology of my Treatise, preserved equality between the rate of saving (as there defined) and the rate of investment. I believed this to be a development and clarification of Wicksell's 'natural rate of interest', which was, according to him, the rate which would preserve the stability of some, not quite clearly specified, price-level. I had, however, overlooked the fact that in any given society there is, on this definition, a different natural rate of interest for each hypothetical level of employment. And, similarly, for every rate of interest there is a level of employment for which that rate is the 'natural' rate, in the sense that the system will be in equilibrium with that rate of interest and that level of employment. Thus it was a mistake to speak of the natural rate of interest or to suggest that the above definition would yield a unique value for the rate of interest irrespective of the level of employment. I had not then understood that, in certain conditions, the system could be in equilibrium with less than full employment." (1973, 1936, 242-243)

${ }^{21}$ As we seem to forget that before Tobin, Dale Jorgenson had also popularized the theory of investment. (Crotty, $1990,8)$
} 


\section{Veblen's $Q=$ Goodwill}

In the 2000s there was a revival of the literature on Veblen, but it did not treat goodwill in relation to Q theory. Bolbol and Lovewell (2001) are the only authors to formulate and develop a Q-Veblen:

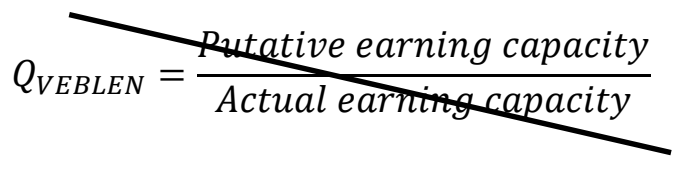

However, we will show that this Q-equation is erroneous. When the Q-Veblen ratio has been corrected, we will show that Veblen's analysis is quite similar to that of all q-theorists, but with an interpretation in terms of "goodwill”. Veblen's notion of goodwill refers to a set of property rights that confer differential advantages in the market. This business potential appears notably in the capitalization of the assets on the company's balance sheet. In this respect, Veblen is an unjustly forgotten author, because he was one of the first to develop a financial theory of the firm..$^{22}$ The link with above-mentioned authors (sections 1 and 2) is the notion of goodwill, proof of his early recognition of the importance of the financial structure and valuation of the company on the market.

Recently, Ali A. Bolbol and Mark A. Lovewell (2001), Craig Medlen (2003) and Dimand (2004) have uncovered a parallel between James Tobin (1969) and Veblen, in their observation of the fragile financial dynamics of capitalism. Bolbol and Lovewell suggested for the first time in 2001 a potential Veblenian Q-ratio. But we do not agree with their definition of the $\mathrm{Q}_{\text {veblen. }}$. Their analysis covers the views of Marx, Veblen and Tobin, dealing with the link between financial market, structure and valuation of the company. They draw a relationship between these three authors, adding that Keynes moved along the same paths. ${ }^{23}$ Despite this, Bolbol and Lovewell only indicate that there may be possible implications for the organizational structure of the company, whereas it is the heart of the

\footnotetext{
${ }^{22}$ Without forgetting T. Greene (1897), W.Z. Ripley (1905), W.H. Lyon (1912), A.B. Norris (1913), and A.S. Dewing (1919) et al.

${ }^{23}$ We strongly believe, like Wesley Pech and Marcelo Milan ("Behavioral economics and the economics of Keynes", 2009), that Keynes knew the writings of Veblen.
} 
Veblenian analysis of goodwill. In 2003, Medlen sought to show that modern Q theory is the legacy of the ideas of Wicksell, Veblen and Keynes, but that:

"Today, the disconnect of modern Q theory from its origins in Veblen's theory of capital is total" (Medlen, 2003, 968)

Even if we completely shared this view that Veblen is disconnected from Tobinan Q theory, it would also have to be the case for Keynes, Myrdal and the influence of Wicksell. In 2004, Dimand traced the affinities between Irving Fisher, Veblen, Hyman Minsky and Tobin concerning the fragilities of financial theory. He emphasized the link with Veblen through the writings of Westley Clair Mitchell. ${ }^{24}$

Yet this literature does not take into account the fact that Veblen's analysis of goodwill does not lead to a theory of investment, as is the case with Keynes, Myrdal or Tobin, but more specifically to a theory of the choice of financial structure. So we wish to emphasize firstly, that the emergence of a Q-Veblen is an assumption made by Bolbol and Lovewell, but that it does not appear as such in Veblen's writings, and secondly, that the central concern of Veblen's goodwill is not investment, but the company's management strategies. We will thus focus on the Q-Veblen that corresponds to goodwill.

For this purpose, it should be noted that Veblen made a real contribution to the theory of capital in the early 20 ${ }^{\text {th }}$ century (Ganley, 2004; Gagnon, 2007; Dieudonné, 2014). The company's value refers to the value of its shares, or at least the expected return on them, which Veblen called the putative earning-capacity. In Veblen's thought, the actual capitalized value "as known to its managers" $(1904,155)$ is the value of the business known by insiders. ${ }^{25}$ On the other hand, the putative value is uncertain and depends on market fluctuations, anticipations and strategic equity capital management. The putative value is actually related to expectations, like the unexpected income stream ${ }^{26}$ in the writings of Keynes and Myrdal:

\footnotetext{
${ }^{24}$ Mitchell, Wesley C. (1936) What Veblen Taught, New York, Viking Press.

${ }^{25}$ And with the knowledge of this value it is possible to manipulate the market in order to extract "secret profits for insiders" (Ripley, 1916, xxii).

${ }^{26}$ Because for Keynes (1936) "each capital and financial asset yields an income stream”, according to Minsky (1993, Comment on Ben Bernanke, 'Credit in the Macro-economy') and income streams are uncertain because they depend on subjective expectations.
} 
"Investment gains and investment losses: these arise if the capital goods just being constructed have, at the moment when they are ready for use, a capital value which is larger or smaller than the total cost of construction. The expectations for such investment gains or losses by the entrepreneurs form the profit motive in the course of Wicksell's dynamic process." (Myrdal, 1933, 1939, 61)

Veblen insists on the fact that the issue of information asymmetry ${ }^{27}$ is the basis of the theory of the non-neutrality of the financial structure in the management of companies:

"The manner in which $[\ldots]$ the discrepancy between the putative and actual earningcapacity of capital, is increased by loan credit during an era of prosperity has been indicated in some detail in Chapter V above." (Veblen, 1904, 194)

The goal is to have a putative earning capacity ${ }^{28}$ greater than the actual earning capacity. So we find a double capitalization as in Wicksell, Keynes or Myrdal, and in Veblen this valuation is a central point of business operation.

Through the appearance of a particular category of surplus value, goodwill, Veblen proposes an accounting analysis of the company and a capital asset model. He adds, "In any case so much seems clear - that goodwill is the nucleus of capitalization in modern corporation finance" $(1904,117)$, an entrepreneurial profit at the heart of early 20thcentury concerns. We intend to show that Veblen's goodwill is actually the investment windfall profits of the Treatise on Money, Myrdal's Q and Tobin's q.

We give a different interpretation of $\mathrm{Q}_{\mathrm{VEBLEN}}$ to that of Bolbol and Lovewell. We

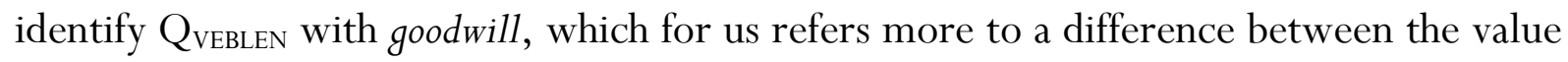
of the company and the replacement cost of capital. Goodwill is a privilege, a differential advantage that appears through a credit leverage effect but also through the capitalization of the firm (and also thanks to a privileged monopoly position).

"In ordinary times, however, and under capable management, the current rate of business earnings exceeds the rate of interest by an appreciable amount." (Veblen, 1904, 96)

\footnotetext{
${ }^{27}$ As in Keynes: "gradual increase in the proportion of [...] equity [...] which is owned by persons who do not manage and have no special knowledge of the circumstances, either actual or prospective, of the business in question." $(1936,138)$

${ }^{28}$ Myrdal was one of the first economists to include expectations theoretically in his economic calculations (André Marchal, 1950). Following the Wicksellian tradition, Veblen evokes a hope of surplus profit. Wicksell just presents an analysis of the price of property defined by the rate of return, which does not involve the capitalized value.
} 
Thus, to illustrate the credit leverage effect and according to Veblen, goodwill appears in the business enterprise when the interest rate $\left(r_{M}\right)$ is less than the current rate of business earning (cber). The capitalization by the two rates $\left(\mathrm{r}_{\mathrm{M}}\right.$ and cber) of the actual earning capacity gives rise to Veblen's Q. Earnings are then capitalized and this goodwill follows from the leverage effect:

$$
\begin{aligned}
Q_{V E B L E N}=\text { Goodwill } & =\frac{\text { actual earning capacity }}{r_{M}}-\frac{\text { actual earning capacity }}{c b e r} \\
\Leftrightarrow Q_{V E B L E N} & =\frac{\pi^{E_{*}} \text { cber }-\pi^{E_{*}} r_{M}}{r_{M} \text { cber }}=\frac{\pi^{E_{*}}\left(\text { cber }-r_{M)}\right)}{r_{M} * \text { cber }}
\end{aligned}
$$

Suppose that the monetary rate is inferior to the current rate of business earning, ie $r_{M}=7 \%$ and cber $=10 \%$. Under these conditions, the capitalization of the actual earning capacity with the market interest rate is structurally higher than it is with the current rate of business earning. The application of these two rates establishes the goodwill, i.e., $Q_{V} \lessgtr 0$.

"New investments are made on the basis of current rates of interest and with a view to securing the differential gain promised by the excess of prospective profits over interest rates." (Veblen, 1904, 218)

We can reconstruct Veblen's thought further using the following balance sheet:

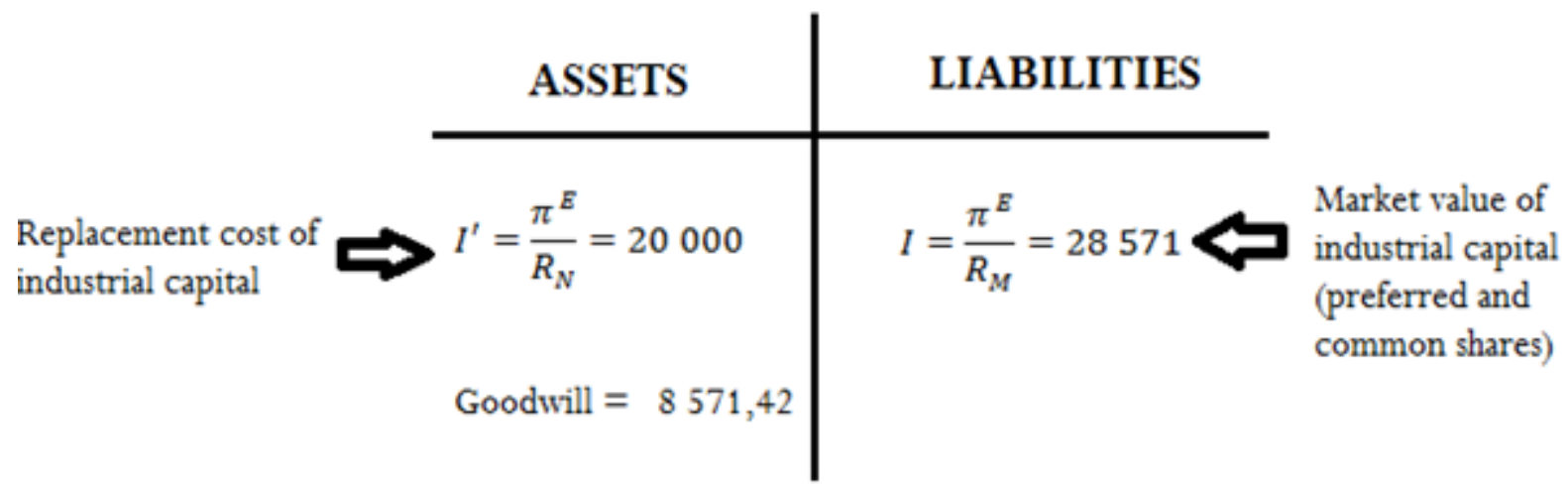

As in the Q theories that we have already presented (1.1), Veblen suggests, in his 1904 business enterprise analysis, that earnings are capitalized by the monetary interest rates which give (I) and, on the other hand, earnings are capitalized with a rate of profit and give a book net value (I').

$$
\text { Goodwill } \equiv Q_{V E B L E N}=I-I^{\prime}
$$


In our previous example, $\mathrm{I}=28,571$ and $\mathrm{I}=20,000$. The actual earning capacity is equal to about 2,000. Thus, we have:

$$
\begin{gathered}
\frac{\text { actual earning capacity }}{r_{M}}=\frac{2000}{0.07}=28571=I \\
\frac{\text { actual earning capacity }}{\text { ber }}=\frac{2000}{0.1}=20000=I^{\prime} \\
Q_{V E B L E N} \equiv \text { Goodwill }=\frac{\pi^{E_{*} \text { ber }-\pi^{E_{*}} r_{M}}}{r_{M^{*} \text { ber }}}=\frac{2000 * 0.1-2000 * 0.07}{0.07 * 0.1}=\frac{60}{0.007} \\
Q_{V E B L E N} \equiv \text { Goodwill }=I-I^{\prime} \cong 8571.42
\end{gathered}
$$

This difference gives rise to the unexpected profits: Veblen's goodwill, the profit motive to Myrdal or the investment windfall profits to Keynes. Thus, Veblen and Myrdal, like Tobin later (R. Shiller, 1999), take the interest rate as a theoretical measure of lending to businesses: new investments take place as a function of profit forecasts, projections even influenced by the proportion of credit in the equity of the company.

Veblen was a very learned man so that in this regard, Vining says:

"Moreover, contemporary with the writings of Veblen were the penetrating discussions by Wicksell of the monetary difficulties of a free-enterprise economy which went much farther along toward a systematic integration of the branches of economic theory." (Vining, 1939, 692)

In the same way, it would be surprising if Myrdal did not read Veblen, since he was in the United States in the late 1920s and early 1930s in the circles of institutionalist academia. ${ }^{29}$ Especially as Myrdal wrote in Against the Stream: Critical Essays on Economics:

"When my wife, Alva Myrdal, and I first came to America at the end of the Twenties for a year as Rockefeller fellows, the 'wind of the future' was institutional economics. This was then the New Economics, as I remember a collection of essays was called. The approach was conceived to be in line with three great American economists: Veblen, Commons and Mitchell, of whom the latter two were still living and active. [...] At that time I was utterly critical of this new orientation of economics. I was in the 'theoretical' stage of my own personal development as an economist.” (Myrdal, 1974, 6).

\footnotetext{
${ }^{29}$ Moreover, in Value in Social Theory: A selection of Essays on Methodology (1958), Gunnar Myrdal emphasizes: "An interesting study, which has, as far as I know, never been attempted, would be to examine more thoroughly the political ideology that underlies American institutionalism. If Veblen can be taken to be its founder, it began with a radical critique of society, apparently influenced by Marx" (228).
} 
The basics of $\mathrm{Q}$ theory run throughout the $20^{\text {th }}$ century from Veblen to Tobin, without forgetting the importance of the work of Wicksell. However, the secondary literature overlooks some interpretations. Especially as this analysis of investment decision in relation to the financial structure allows us to introduce Veblen as the pioneer of the analysis of managerial performance. In fact, the "visible hand" is central in discussions about business management and sensitivity to the choice of capital structure. Therefore, Veblen has an investment vision that involves a necessary reorganization to deal with the tensions in the financial structure. While contributing to a collective effort of theorizing, he maintains his independence and uniqueness notably because of the particular context in which he operates, at the edge of managerial capitalism and the transformation of the productive system in industrial and financial conglomerates.

\section{Veblen's Q, management and absentee ownership}

At the turn of the century, new strategies emerged, not only industrial but also commercial and financial. It is in this context that the analysis of Veblen and the themes of corporate finance literature become important. Challenges appear in terms of capitalization, the credit leverage effect, conflicts between shareholders and managerial revolution.

In previous sections we have shown that through his analysis of goodwill, Veblen joined economists like Keynes, Myrdal and Tobin and thus played a role in the Q theory tradition. However, we also need to underline the novelty introduced by Veblen regarding analysis of the investment decision. For Veblen, the knowledge of and possibility of acting on the market capitalization are the bone of contention between the two kinds of shareholders. It is the central issue of a functional distinction between managers and owners. However, in comparing the Q-theorists and Veblen, two distinct logics emerge in the analysis of their ratios.

Despite this difference in objectives and interests, it appears logical to include Veblen's reasoning within the Tobin's q approach, by the evident filiation which developed 
over several decades of the $20^{\text {th }}$ century, and as a symbol of the formation of debate and emergence of practical problems concerning the operation of business and markets. ${ }^{30}$ Veblen's goodwill $\left(\mathrm{Qv}_{\mathrm{EBLEN}}\right)$ allows the author to develop an investment analysis that is not restricted to the investment costs of the means of production. Rather, it opens the door to a more comprehensive analysis: that of the financial structure of the enterprise. Therefore, in creating a valuation gap (I-I') that causes a change in the financial structure, Veblen uses the Qv to explain the nature of shares and change the scope of business management.

Thus, while Q theory is based on the company's investment strategy, Veblen's Q leads us to reconsider the logic of investment. This is not the productive aspect of the business that is put forward by Veblen. For Veblen, the productive aspect is "far from understanding discrepancies in capital valuations as strategic for growth” (Medlen, 967), and far from just "considers [...] the role of asset prices in stimulating new capital investment" (Tobin and Golub, 1998, 146) but the secondary literature explains nothing beyond this.

While Q-theorists have pure investment concerns, and focus on the "effects on the amount of real investment" (Myrdal, 1939, 78), Veblen includes a strategic management dimension through the common shareholders and the appearance of absentee ownership. This capitalization structure does not appear in Tobin.

While it appears obvious in previous sections that Qv is similar to the other ratios, actually the Q tradition does not exhaust the subject and Veblen demonstrated originality in his analysis. That is why it is important not to omit the Theory of Business Enterprise from the tradition of the theory of investment. In fact, it is more a theory of the capitalization of earnings and of the distribution of this capitalization between preferred and common shares. Veblen's writings attach importance to the distinction between these two kinds of

\footnotetext{
${ }^{30}$ In addition, an extensive literature exists on Tobin's q (see footnote 17, but also Hayashi (1982), Baxter and Crucini (1993)), which appears as an important gauge to measure business behavior and as a way of modeling that emerged in the 1970s. This is a basic model which summarizes the useful information and puts profitability and investment into perspective, hence the popularity of this ratio. The better understanding of company behavior is the result of modeling efforts over the long term, by several theorists, to obtain the necessary estimation methodology.
} 
shares (see M. Dieudonné, 2014). Veblen analyzes the financial structure and its effects on management issues.

"But in so far as such buying and selling [of stocks] is carried on by the managers of the corporations whose securities are the subject of the traffic, and especially where the securities are bought and sold with a view to the control of the corporations in question and their management for private, tactical ends, a characterization of the business as "speculative" is inadequate and beside the point." $(1904,165)$

Decisions are taken while common shareholders know that they can keep the majority of the company's control and potentially manipulate the value of goodwill. This is clear with the emergence of the joint-stock company; the mood of the market economy leaves room for elaboration of Rudolph Hilferding's concept of promoter's profit (Financial Capital: a study of the latest phase of capitalist development 1910,1981). Thus, there is uncertainty about the objective function of managers, and the managerial structure disrupts the investment logic.

Thus, the creation of shareholder value is not the first consequence of the investment decision, because Veblen's analysis reflects a more lasting motivation, as the concern of business management. While Tobin's $\mathrm{q}$ is seen as a tool for understanding investment choices and the prediction of their profitability, Veblen presents goodwill as a financial incentive in managerial interests and not just a speculative return on ownership. Herein lies all the ingenuity of Veblen, who theorizes the importance of a distinction between common and preferred shareholders. While the authors of Q theory seek to create and maximize the return on investment of their shareholders and Tobin confuses ownership and management functions (Crotty, 1990, 521), Veblen is concerned by managerial motivations. In fact, in Veblen's opinion, it is the work of corporate managers to maximize the differential value between actual and putative earnings ${ }^{31}$ and their capitalization:

\footnotetext{
31 "The question of fair prices and reasonable profits has some reference to current rates of interest. [...] New investments are made on the basis of current rates of interest and with a view to securing the differential gain promised by the excess of prospective profits over interest rates." "The question of the turnover becomes, under the circumstances of the modern corporation finance, in great part a question of the interval between the purchase and sale of the capital engaged in industry on the one hand, and of the magnitude of the discrepancy between actual and putative earning-capacity on the other hand, rather than a question of the period of the industrial process and the magnitude of the output and its price." (Veblen, 1904, 218 and footnote 102)
} 
"When, e.g., the putative earning-capacity of the capital covered by a given line of securities, as shown by the market quotations, rises appreciably above what is known to its managers to be its actual earning-capacity, the latter may find their advantage in selling out, or even in selling short; while in the converse case they will be inclined to buy." (Veblen, 1904, 155)

In 1904, he emphasized that the managerial rationale outweighs investment concerns. This additional valuation refers more to a proxy of managerial performance than to share performance. Moreover, the secondary literature on the relation between Veblen and Tobin's q focuses on information asymmetries. But Tobin has no managerial concerns, he just focuses on maximizing shareholder value:

"Tobin's model is a neoclassical general equilibrium model. All agents in this model have identical information and form identical, conditionally correct expectations of the future. Since enterprise management and the firm's stockholders also have the same objectives, there is nothing that management knows, expects, or desires that is not simultaneously known, expected, and desired by the stockholders. There is a complete conflation of ownership and management.” (Crotty, 1990, 9)

The innovative character of Veblen's work lies in the scope of the hybrid nature of shares reflected in the putative and the actual earning-capacity (Dieudonné, 2014). That is why Veblen seeks the maximization of common shares, since managers are the largest common shareholders, and why he appears as an analyst of business management through Q theory. A similar analysis of business management can be found in the writings of Marx (18641875), Hilferding (1910) or Berle and Means (The Modern Corporation and Private Property, $1932) .^{32}$

Berle and Means, generally considered the pioneers of managerial capitalism, deal with the enterprise as a central social institution and also take Veblen as a reference. ${ }^{33}$

"The corporation has, in fact, become both a method of property tenure and a means of organizing economic life. Grown to tremendous proportions, there may be said to have evolved a "corporate system" - as there was once a feudal system — which has attracted to itself a combination of attributes and powers, and has attained a degree of prominence entitling it to be dealt with as a major social institution.” (Berle and Means, 1932, 3)

\footnotetext{
${ }^{32}$ However, even the comprehensive article of Hannah (2007) “The 'divorce' of ownership from control from 1900 onwards: re-calibrating imagined global trends” does not cite Veblen for these changes in the operation of the company's management.

${ }^{33}$ Keynes, in 1936, also made the company a central institution of the economy, in the passage about casino capitalism in Chapter 12.
} 
Veblen is quoted as early the first paragraph of their 1932 book, because he has an undeniable intellectual connection allowing Berle and Means to establish their theory of modern enterprise.

"The cynical view of many historians insists that property interests have at all times, visible or invisible, been dominant. Following this grim analysis, one commentator on the rise of corporations observed that they had become the 'master instruments of civilization' (Veblen, 1923).” (Berle and Means 1932, 2)

And yet, while Veblen thus appears to have been very influential, he has had a rather lean posterity in corporate analysis, and only the names of Marx and Berle remain:

"Berle had the bold ambition of becoming the prophet of the share-holding class, or as he so modestly put it, 'the American Karl Marx.'” (F. Stewart, 2011, 1465)

Veblen is in the tradition of Marx and understood before the 1930s the role of the financial structure in business management: they both prioritize the internal structuring of the operation of the company and make it a central issue. The technostructure almost replaces the entrepreneur, who becomes one capitalist among others. Veblen stimulated a tradition of corporate analysis, a new order with a modern vision of the firm and new standards. He was aware of the industrial revolution taking place with the delegation of management by the owner. Thus, Veblen anticipated the announcement of the managerial revolution described by Berle and Means. The fact that managers put pressure on shareholders was not a novelty in the 1930s. And the prices and trends clearly showed the fragility of the financial capital economy.

\section{Veblen's goodwill and Hilferding's promoter profit}

Moreover, once the role of Veblen's Q in the filiation has been highlighted, we must emphasize that the literature that has previously identified a Veblen's Q does not perceive that the central issue is the management of the firm. We must therefore bring to light the major role of earnings generation and its capitalization - a concern that can be found in both Veblen and Hilferding.

This tradition of analyzing changes in the company is not specific to the early 20 th century. Karl Marx had already noted the changes taking place in the financial markets. His view of finance and his socio-political vision of the capitalist system was linked to his 
conceptual analysis of the large company, leaving a legacy taken up by Veblen and Hilferding:

"But the fact that, first, rent is limited to the excess above the average profit, and, secondly, the landlord is depressed by the ruler and manager of the process of production and of the entire social life's process to the position of mere holder of land for rent, a usurer in land and collector of rent, is a specific historical result of the capitalist mode of production.” (Marx, Capital, Vol III, 1029)

Although the impact of large-scale financial and commercial activities and the socialization of property are themes addressed in the 1920s and 1930s, the late 19th century was conducive to the emergence of these debates. Capital initiates a process of centralization and big businesses become a separate institution. The literature developed a MarxHilferding parentage but overlooked Veblen, ${ }^{34}$ while the notion of surplus, central for capitalism at the turn of the century, was also developed in his writings. This notion, without any productive use, was a central theoretical basis for capitalism at that time. The link between firm size, investment theory and surplus seems obvious.

In fact, Marx was the first to initiate a reflection on management, among the earlier authors who studied entrepreneurial functions. ${ }^{35}$ In Volume III of Marx's Capital, published in 1968 by Maximilien Rubel, it is interesting to note the remark he made on the form of capitalist production with separation between management and ownership. According to Marx, the capitalist therefore disengages from the manager. ${ }^{36}$

"Stock companies in general, developed with the credit system, have a tendency to separate this labor of management as a function more and more from the ownership of capital, whether it be self-owned or borrowed" (Marx, 1909, 456)

and Rubel added:

"Marx formule ici d'une manière lapidaire la thèse qu'exposent soixante ans plus tard A.A. Berle et G.C. Means dans l'Entreprise moderne et la Propriété privée, 1932. Elle peut servir d'épigraphe à toute analyse sociologique des fonctions directoriales dans les grandes

\footnotetext{
${ }^{34}$ Although there are Bolbol and Lovewell (2001) and Stravelakis (2013) Hilferding over Marx: a political economy viewpoint of struggles in the left 1900-1933 and the modern revival. See also Jérome de Boyer "Marx and Hilferding on profit of enterprise and promoter's profit" (2015).

${ }^{35}$ See Sophie Boutillier, 2010, "L'entrepreneur artisan. Entreprendre et dynamique du capitalisme essai d'analyse d'Adam Smith à David Audretsch" for an interesting summary.

36 "Ce ne sont pas les capitalistes industriels, mais les managers qui sont l'âme de notre 'système industriel”" (1968, 1147 Le Capital, Livre III, Cinquième section, Chap. 15)
} 
sociétés et entreprises capitalistes jouissant du droit de la propriété privée ...” (Rubel, $1968,1786)^{37}$

Managers and capitalists have different and opposing interests through their respective active and passive functions in the company. We can note the difficulty of the terminology and the concepts of contractor and capitalist used at the beginning of the $20^{\text {th }}$ century. Indeed, the concept of entrepreneurship gradually disappears from the literature. The entrepreneur, whether capitalist or not, gives way to the conflict of interest between owner-managers and owner-shareholders. The figure of the entrepreneur is no longer appropriate. In Veblen, there are Captains of Industry and Captains of Finance, working owners and absentee owners called "vested interests". The terminology changes. For the latter, Marx already speaks of "passive capitalists" and he actually talks of financiers, the market-takers who develop fictitious capital. He also derived the notion of captains of industry: "Industriekapitäne" (Capital, 1867, 1872, volume 1, 457). Thus, they both foreshadow the initial signs of the managerial revolution, as Rubel pointed out in 1968 about Marx without mentioning the contribution of Veblen: the managerial element has a special place in the business results in both $\mathrm{Marx}^{38}$ and Veblen. Rubel notes in Book 3 of Capital $(1968,1786)$ that Marx's analysis of the mode of production is rooted is based on consideration of the contemporary development of the corporate structure. Early in the century, Hilferding ${ }^{39}$ inscribed himself as the successor of Marxist thought: "My analysis of the economics of the corporation goes considerably beyond that provided by Marx" (1910, 1981, 114). Veblen seems to follow the same path. And ultimately, the management that we call "capitalist management" is more a culture of "managerial management”. Moreover, more than following the same path, Veblen actually goes beyond Marx, who remains quite vague about the internal management structure of the firm, by bringing to light this

\footnotetext{
37 "Here Marx succinctly formulates a thesis that was proposed sixty years later by A.A. Berle and G.C. Means in The Modern Corporation and Private Property, 1932. It can be used as an epigraph to any sociological analysis of managerial functions in large capitalist firms and companies possessing the rights of private property [...]"

38 "C' est maintenant les capitalistes industriels et commerciaux qui dictent les conditions au capitaliste financier" (Marx, 1894, 1959, 156)

${ }^{39}$ In addition, Hilferding drew on Marx to develop his analysis of leverage that allows him to propose a promoter's profit: "neither a swindle, nor some kind of indemnity or wage. It is an economic category sui generis" (Hilferding, 1910, 112), but both Veblen and Hilferding make the same mistake in using a capitalization rate that does not include a risk premium (De Boyer, 2003).
} 
managerial logic. We could even consider that Veblen adopts an opposite reasoning to Marx, since he considers that managers gradually become a new entrepreneurial authority by taking over the power of decision from the old directional elite.

Furthermore, both Marx and Veblen, but also Hilferding, emphasize the very special role played by credit ${ }^{40}$ through the credit leverage effect that is at the root of these conflicts for power and the capture of capitalization surplus. The analysis is similar and the intellectual influence seems obvious. ${ }^{41}$

"In his brilliant sketch of the role of credit in capitalist production, ${ }^{42}$ which he was unfortunately denied the opportunity to elaborate, Marx conceives the corporation as a consequence of the credit system." (Hilferding, 1910, 1981, 114, our italics)

\section{We find the same reasoning in Veblen:}

"In ordinary times, however, and under capable management, the current rate of business earnings exceeds the rate of interest by an appreciable amount; and in times of ordinary prosperity, therefore, it is commonly advantageous to employ credit in the way indicated." (Veblen, 1904, 96, our italics)

The challenge is to duplicate the structure of credit $^{43}$ through interest rates, the financial structure resulting in predatory operations in the firm's activities.

"The motive of business is pecuniary gain, the method is essentially purchase and sale. The aim and usual outcome is an accumulation of wealth. Men whose aim is not increase of possessions do not go into business, particularly not on an independent footing." (Veblen, 1904, 20)

The profitability of equity depends on the discrepancy between the rate of return on capital and the borrowing interest rate.

"[...] the profit of enterprise results from the gross profit after deduction of administration costs and interest, including the risk premium, on borrowed capital. The capitalization of this profit gives rise to the promoter's profit.” (de Boyer, 2015, 14)

\footnotetext{
${ }^{40}$ Marx speaks of "a whole system of swindling and cheating" (Capital, Vol III, chapter 27), what is call "tripotages de crédit” in the French version (1968, 1786).

${ }^{41}$ See P.H O’Hara “Veblen's critique of Marx’s philosophical preconceptions of political economy” (2006) and A.H Mouhammed “A Critique of A Marxist Critique of Thorstein Veblen” (2008).

42 "But this centralization, which only redistributes the social capital already to hand, and melts a number of old capitals into one, works in its turn as a powerful agent in the metamorphosis of old capital's most powerful levers of centralization - competition and credit." (Annotations to Karl Marx's Capital by Hans Ehrbar (2000). Available at http: / / marx.economics.utah.edu/das-kapital/akmc/cic25.htm).

${ }^{43}$ We find the same idea in Tobin and Golub: "if new debt or equity securities are issued to raise the cash, the successful prospectus leads to an increase of share prices.” $(1995,149)$
} 
Thus, in the same way as Hilferding's entrepreneurial profit, Veblen defines goodwill as the difference between the market value and the equity value of the company. In addition, Hilferding highlights

"The increase of entrepreneurial profit through the use of credit $[\ldots]$ does, of course, increase the total sum of profit and accelerate the pace of accumulation. Those capitalists who use credit before others [...] gain initially an extra profit." (1910, 1981, 93, our italics)

For Veblen, a leverage effect is created through the issuance of new preferred shares whose $r_{M}$, rate with a potential added risk premium, remains below the $r_{N}$. While Hilferding subtracted the value of the own capital at the stock market value, Veblen did the same with the actual earning capacity at the market rate and the earning capacity at the natural rate to obtain a "differential gain promised by the excess of prospective profits" (Veblen, 1904, 218). Each time, the same yield is capitalized at two different rates, reflecting credit conditions and profit opportunities. The use of credit increases the promoter's profit as well as goodwill, until the cost of borrowing equalizes the capitalization rate (de Boyer, 2015; Dieudonné, 2014).

But even without borrowing capital, we can highlight the appearance of Veblen's goodwill and Hilferding's promoter's profit. What applies in Veblen can be applied in exactly the same manner in Hilferding. We use the same notation as in the article by de Boyer, "Marx and Hilferding on profit of enterprise and promoter's profit" (2015), and the same example as in Part I:

"[8571] represents the difference between the yield [2000 of gross profit] capitalized at [10] per cent and the same yield capitalized at 7 per cent; or in other words, the difference between capital which earns the average rate of profit and capital which earns the average rate of interest" (Hilferding, 1910, 112, in de Boyer, 2015, 15)

$$
\begin{gathered}
\text { Promoter's profit }=\text { stock market value }- \text { own capital } \\
\frac{\text { profit of enterprise }}{r_{M}}=\frac{2000}{0.07}=28571=\text { market value }=\mathrm{I} \\
\frac{\text { profit of enterprise }}{r_{N}}=\frac{2000}{0.1}=20000=\text { own capital }=\text { replacement value of real capital = I' } \\
\text { So, Hilferding Promoter's profit }=\text { Veblenian Goodwill }=I-I^{\prime} \cong 8571.42
\end{gathered}
$$

Veblen, like Hilferding, introduced a reasoning based on the idea that credit makes it possible to increase the financial value of the company. This was called into question by the Modigliani-Miller theorem (1958), because the increase in the debt risk is not taken into 
account. If a risk premium is added, taking into account the additional risks involved in the loan, then goodwill and promoter's profit actually disappear. The financial structure (i.e., the proportion of debt to equity) is not neutral for Veblen: profitability differentials are based on debt. The company's value is then disconnected from its financial structure because of the existence of two different rates through two types of shareholders. It follows a difference in profitability between investments. This conclusion is clearly different from that of modern theory, the famous Modigliani-Miller theorem which states that the company's financing plays no role in its value. All corporate finance in the first half of the 20th century was structured on the opposite idea. Therefore, it took until 1958 to recognize the error in understanding common to these pre-modern writers. Now, the arbitration between the market value and book value of a firm's equity no longer relevant.

We have just seen that Veblen, through the credit leverage effect and goodwill, creates a decision tool for shareholders rather than an indicator for pure investment. These concerns are also present in modern financial theory. Moreover, at the turn of the century, the company was becoming a complex organization. This phenomenon was perceived, in parallel to the evolution of financial markets, both in the US and Europe. Veblen, like Marx and Hilferding, sought to explain that there is a qualitative division of profit between interest and entrepreneurial profit. The idea of a dominance of finance over industry was needed. But obviously, these theorists on both sides of the Atlantic have practiced a dichotomy in their influences and references. Nevertheless, all these developments and thoughts then gave rise to a new discipline with the first stages of corporate finance.

\section{Conclusion}

Since Modigliani and Miller, the business financing method (capital structure) has not played any role in the company's value. And yet the economic tradition has long recognized the importance of credit in the financial structure of the company and its decisions. Indeed, until 1958, the company's profitability and its market valuation were considered to improve with debt. The Modigliani-Miller theorem highlights the need to specify the terms of the neutrality of the financial structure. Veblen was a very early 
proponent of this approach linking corporate finance, investment and financial structure. In 1904 he showed the non-neutrality of the financial structure. Debt finance was a suitable investment strategy for manipulation. On this point, in 1958, the Modigliani-Miller theorem challenged all the analysis that had preceded it. However, Veblen theorized goodwill and was a pioneer of corporate finance, considering market valuation and the choice of financial structure as central to the operation of the business. The difference between a company's market value and investment value has an impact on the management of the firm and the redistribution of ownership, and not just on maximizing shareholder value as in Myrdal and Tobin. In this, Veblen was probably inspired by the writings of Marx and Wicksell, and he focused on the same issues as Hilferding or Berle and Means. Veblen was part of a flow of highly innovative North American thought in the early 20th century (including the theory of capital) that deserves more attention. But the literature completely overlooks the roots of the theories developing before the 1930s, even though they are a valuable resource for understanding the debates and events of the time. Thus, Q theory was much investigated without considering its Veblenian origins until the 2000s, despite the fact that Veblen gave us the first intuitions of a simple model of earning assets valuation. For all these reasons, it is important not to neglect Thorstein Veblen in the rational reconstruction of $\mathrm{Q}$ theory and in analyses of inside-outsider theory and corporate finance.

\section{Bibliography}

Berle, A.A. \& Means, G.C. (1932). The Modern Corporation and Private Property, Ed. Macmillan, New York, 1932.

Boianovsky, M. (2013). Fisher and Wicksell on money: A reconstructed conversation. The European Journal of the History of Economic Thought, 20(2), 206-237.

Bolbol, A.A. \& Lovewell, M.A. (2001). "Three views on stock markets and corporate behavior: Tobin, Veblen and Marx", Journal of Post Keynesian Economics 23, no.3 (April 1, 2001): 527-543.

de Boyer des Roches, J.

- (1982). "Demande effective et théorie monétaire”, Cahiers d'économie politique, 8(1), (1982) :5164.

- (1988). Irving Fisher, great-grandparent of the "General Theory": un commentaire. Cahiers d'économie politique/Papers in Political Economy, 69-73.

- (2003). La pensée monétaire: Histoire et analyse, Ed. Les Solos, Paris, 2003.

- (2015). "Marx and Hilferding on profit of enterprise and promoter's profit", 2015.

Cobbaut, R. (1987). Théorie financière, Ed. Economica, Paris, 1997. 
Cochrane, D.T. (2011). Castoriadis, Veblen and the "Power Theory of Capital", in I.S. Straume and J.F. Humphreys (eds), Depoliticization: The Political Imaginary of Global Capitalism, Aarhus: Aarhus University Press, pp. 89-123.

Crotty, J.R.

- (1990). "Owner-manager conflict and financial theories of investment instability: a critical assessment of Keynes, Tobin and Minsky", Journal of Post Keynesian Economics, (1990):519-542.

- (1992). "Neoclassical and Keynesian Approaches to The Theory of Investment", Journal of Post Keynesian Economics 14, no.4 (Summer 1992):483-496.

Dieudonné, M. (2014). "Credit, Shares and Goodwill: A Veblenian Trinity”, work in progress presented at the 2014 ESHET Conference, the 2014 Gide Conference and the Summer School of History of Economic Thought.

Dimand, R.W.

- (2004). "Echoes of Veblen's Theory of Business Enterprise in the Later Development of Macroeconomics: Fisher's Debt-deflation Theory of Great Depressions and the Financial Instability Theories of Minsky and Tobin.” International Review of Sociology 14, no. 3 (2004): 461470 .

- (2014). "Tobin's q and the Theory of Investment” in James Tobin. Palgrave Macmillan, 2014.

Dirlam, J.B. (1958). "The place of corporation Finance in Veblen's Economics”, Thorstein Veblen: a critical reappraisal, 1958: 199-219.

Ely, RT. (1906). Monopolies and trusts, Grosset \& Dunlap, 1906.

Ely, RT, Adams, TS, Lorenz, MO, Young, AA. (1919). Outlines of Economics, New York, 1893.

Ganley, W.T. (2004). “The Theory of Business Enterprise and Veblen's Neglected Theory of Corporation Finance.” Journal of Economic Issues 38, no. 2 (June 1, 2004): 397-403.

Gagnon, M.A. (2007). "Capital, Power and Knowledge According to Thorstein Veblen: Reinterpreting the Knowledge-Based Economy", Journal of Economic Issues 16, No.2 (June, 2007): 593-600

Hilferding, R. (1981). Financial capital: a study of the latest phase of capitalist development. Routledge \& Kegan Paul, 1910 .

Hobson, J. A. (1936). Veblen, London: Chapman and Hall, 1936.

Hill, Forest G. (1967). "Veblen, Berle and the Modern Corporation" American Journal of Economics and Sociology 26, no. 3 (July 1, 1967): 279-295.

Keynes, J.M.

- (1965). A Treatise on money: the applied theory of money: Volume 1: The Pure Theory of Money, London: Macmillan \& Co., Ltd., 1930.

- (1973). The General Theory of Employment Interest and Money. The Collected Writings of John Maynard Keynes: Part VII, Macmillan for the Royal Economic Society, 1936.

- (1937). "The ex ante theory of the rate of interest", The Economic Journal, December 1937, pp. 663-669.

Kregel, J. (1988). Irving Fisher, great-grandparent of the "General theory": money, rate of return over cost and efficiency of capital. Cahiers d'économie politique/Papers in Political Economy, 59-68.

Le Bot, F. (2014). "Capitaines d'industrie” in Dictionnaire sociologique de l'entrepreneuriat. Paris, Presses de Sciences Po, 2014.

Lefebvre, J-P. (1993). Edition de Karl Marx, Le Capital, livre I. Ed.Quadrige, PUF, Paris, 1983.

Lindenberg, E.B., and Ross, A.S. (1981), “Tobin's q ratio and Industrial Organization”, The Journal of Business, Vol.54, No.1, (Jan., 1981): 1-32.

Marchal, A. (1950). “L'apport des Suédois à la théorie économique contemporaine. 'L'équilibre monétaire’ de Gunnar Myrdal”, Revue Economique Vol.1, n4, (1950) : 498-507.

Marx, K.

- (1968). “Le Capital - Critique de l'économie politique, livre troisième”, Edition de M. Rubel, in Karl Marx, Euvres II, Paris : Editions Gallimard, "La Pléiade”, 1894. 
- (1962). Capital, Book 2, Engel's publication in 1885, English publication by Eden and Cedar Paul, London , 1863-1878, 1930.

- (1959). Le Capital: Critique de l'économie politique, livre troisième, tome II, édition F. Engels, Paris: Editions sociales, 1894.

- (1909). Capital, Book 3, Engels's publication in 1894, English publication by Charles H. Kerr \& Co, Chicago, 1864-1875.

- (1903). Das Kapital: Kritik der politischen Oekonomie, (Vol. 1). F. Engels (Ed.). Hambourg O. Meissner, 1872.

Medlen, C. (2003). “Veblen's Q, Tobin's Q”, Journal of Economic Issues, Vol.37, No.4 (Dec 2003):967986.

Mendez, J. (2012). Théories pré-keynésiennes de l'instabilité financière: Marx, Veblen, Hawtrey. PhD dissertation, 2012.

Modigliani, F., and Miller, M.H. (1958). "The cost of capital, corporation finance and the theory of investment." The American Economic Review, Vol.48, N³, (1958): 261-297.

Morck, R.K, and Steier, L. (2005). "The global history of corporate governance: An introduction". In $A$ history of corporate governance around the world: Family business groups to professional managers. University of Chicago Press, (2005): 1-64.

Myrdal, G.

- (1931). "Om penningteoretisk jämvikt. En studie över den "normala räntan" i Wicksells penninglära”. Ekonomisk Tidskrift, Årg. 33, häft 5/6 (1931):191-302; german version, (1933).

- (1965). Monetary equilibrium. London: Hodge, 1939.

Ripley, W.Z. (1916). Trust, Pools and Corporations. Ed.Ginn, 1905.

Rutherford, M.

- (1980). "Veblen on Owners, Managers, and the Control of Industry," History of Political Economy 12, no. 3 (September 21, 1980): $434-440$.

- (2011). The institutionalist movement in American Economics, 1918-1947: Science and social Control. Cambridge University Press, 2011.

Schmidt, K.J.W. (1995). "Tobin's q? - Myrdals Q! ein Fallbeispiel für den Wert von Fremdsprachenkeantaussen”. Kredit und Kapital 28, Issue 2, (1995): 175-200.

Stabile, D. (2005). Forerunners of Modern Financial Economics: A random walk in the history of economic thought. Edward Elgar Publishing, 2005.

Stewart, F.L.Jr. (2010). "Berle's Conception of Shareholder Primacy: A Forgotten Perspective for Reconsideration during the Rise of Finance", Seattle UL Revue 34, (2010): 1457-1499.

Tobin, J.

- And Brainard, W.C. (1968). "Pitfalls in financial model building". The American Economic Review, (1968):99-122.

- (1969). "A general equilibrium approach to monetary theory". Journal of money, credit and banking, Vol. 1, No. 1 (Feb., 1969):15-29.

- And Brainard, W.C. (1977). "Asset markets and the cost of capital". Economic Progress, Private Values and Public Economic Journal, 96, (march 1977): 120-138.

- And Golub, S.S. (1998). Money, Credit and Capital, Mc Graw-Hill/Irwin, 1998.

Veblen, T.B.

- (1978). The Theory of Business Enterprise. Transaction Publishers, 1904.

- (1908). "Fisher's Capital and Income", Political Science Quarterly, volume 23, 1908.

- (1997). Absentee Ownership: Business Enterprise in Recent Times: the Case of America. Transaction Publishers, 1923.

Vining, R. (1939). "Suggestions of Keynes in the Writings of Veblen". Journal of Political Economy, Vol.47, No.5 (October, 1939): 692-704.

Wicksell, K. (1936). Interest and Prices. Macmillan and Co, 1898. 


\section{Thorstein Veblen's 1904 contributions to $Q$ and insider-outsider analyses Marion Dieudonné*}

The beginning of the $20^{\text {th }}$ century saw the first steps in a tradition of leading economists explaining the link between corporate finance, investment and financial structure. The writings of John Maynard Keynes (1930), Gunnar Myrdal (1931, 1933) and James Tobin (1969) deal with the development of an investment theory based on the financial structure. In this context, we give a new presentation of Wicksellian and Keynesian theories. The initial impetus given by Knut Wicksell (1898) with his system of two interest rates must be emphasized (Schmidt, 1995). However, these studies do not mention Thorstein Veblen (1904, 1908, 1923), one of the founding fathers of institutionalism, who remains unknown, particularly in this tradition, although recent literature (Ganley, 2004; Gagnon, 2007; Cochrane, 2011; Mendez, 2012) considers that he made a real contribution to capital theory. He made an early American analysis of corporate governance structure, which emerged as a central issue in the early $20^{\text {th }}$ century in light of the development of financial instruments, shareholder behavior and corporate equity valuation concerns. Our work is based on a critical review of the literature, which is guilty of omissions, lack of accuracy and errors of formalization. The theory of the non-neutrality of the financial structure remains wholly relevant today, so that in this paper, we focus on the reasons why Veblen's corporate financial analysis should not be forgotten.

Codes JEL: B15, D24, D46, D72, E22, G32, G34

Key Words: capital valuation, corporate governance, financial structure, goodwill, investment theory, Keynes, promoter's profit, Myrdal's Q, Tobin's q, Veblen, Wicksell, windfall profits.

\footnotetext{
* PhD Student, Université Paris-Dauphine, PSL Research University, LEDa, [SDFI], 75016 PARIS, FRANCE emails: mariondieudonn@yahoo.fr ; marion.dieudonne@dauphine.fr

I would like to thank Jérôme de Boyer des Roches for his valuable discussion, Thierry Granger for his interesting comments at the doctoral seminar in Dauphine in April, 2015 and Maria-Luisa Ratto for his valuable proofreading.
} 